\title{
Opportunity and Threat of Developing Halal Tourism Destinations: A Case of Banjarmasin, Indonesia
}

\author{
Mochammad Arif Budiman ${ }^{1}$, *, Manik Mutiara Sadewa ${ }^{1}$, Lusiana Handayani ${ }^{1}$, \\ Mohamad Soleh Nurzaman ${ }^{2}$, Fithra Faisal Hastiadi ${ }^{3}$ \\ ${ }^{1}$ Department of Accounting for Islamic Financial Institutions, Politeknik Negeri Banjarmasin, Banjarmasin, Indonesia \\ ${ }^{2}$ Department of Islamic Economics, Faculty of Economics and Business, Universitas Indonesia, Depok, Indonesia \\ ${ }^{3}$ Department of Development Economics, Faculty of Economics and Business, Universitas Indonesia, Depok, Indonesia \\ Email address: \\ m.arif.budiman@poliban.ac.id (M. A. Budiman), manikmutiara@akuntansipoliban.ac.id (M. M. Sadewa), \\ lusiana.handayani@poliban.ac.id (L. Handayani),dedenmsn@gmail.com (M. S. Nurzaman), fithra_faisal@yahoo.com (F. F. Hastiadi) \\ ${ }^{*}$ Corresponding author
}

To cite this article:

Mochammad Arif Budiman, Manik Mutiara Sadewa, Lusiana Handayani, Mohamad Soleh Nurzaman, Fithra Faisal Hastiadi. Opportunity and Threat of Developing Halal Tourism Destinations: A Case of Banjarmasin, Indonesia. International Journal of Economic Behavior and Organization. Vol. 7, No. 1, 2019, pp. 7-13. doi: 10.11648/j.ijebo.20190701.12

Received: January 17, 2019; Accepted: February 21, 2019; Published: March 6, 2019

\begin{abstract}
Banjarmasin is a unique city and well known as a City of Thousand Rivers (Kota Seribu Sungai). There are many potential halal tourist destinations in the city primarily those related to rivers and the Islamic life of the people. However, these potentials have not been developed adequately for tourism. As such, the aim of this study is to reveal the potentials of halal tourism in Banjarmasin and to assess the opportunity and threat in developing the city as a favorite halal tourist destination in Indonesia. For that reason, the Global Muslim Travel Index (GMTI) 2018 became the referred standard. The study was conducted with a qualitative approach and analyzed by using the descriptive-analytical method. The study reveals that Banjarmasin has the treasure of religious, natural, historical as well as shopping and culinary tourist destinations. The religiosity of the people that is reflected in their cultural life is also interesting to be observed. All these provide a big opportunity to attract both domestic and foreign visitors. But at the same time, the city still faces some threats especially in terms of lack of access, communication, and services that need to be seriously overcome by all relevant stakeholders.
\end{abstract}

Keywords: Halal Tourism, Tourism Destination, Religiosity, Islam, GMTI

\section{Introduction}

The tourism industry is one of the largest and most rapidly growing economic sectors in the world. It has become one of the main industries producing foreign exchange in many countries. Tourism is seen as a key sector capable of creating jobs and generating income for industry and government [1]. The number of international travelers is increasing steadily over time, from 25 million tourists (1950), 278 million (1980), 528 million (1995), and 1,138 million (2014) [2].

Indonesia is a country that is bestowed with the beauty of natural panorama and the richness of cultural heritage and historical sites. This circumstance has attracted many domestic and foreign tourists to attend. As the most populous Muslim country in the world, Indonesia has also many halal tourist destinations which are recognized worldwide. Based on the Global Muslim Travel Index (GMTI), Indonesia has gained a better position in managing the halal industry in the last four years. In 2015, Indonesia's score was 67.5 and laid in the $6^{\text {th }}$ behind Malaysia, Turkey, the United Arab Emirates, Saudi Arabia, and Qatar. But in 2016, Indonesia's rank was the $4^{\text {th }}$ and then constituted the $3^{\text {rd }}$ in 2017. Amazingly, in 2018 Indonesia's score is further increased (72.8) and becomes the $2^{\text {nd }}$ rank behind Malaysia [3]. This greater recognition from the international halal market shows the improved performance of halal tourism industry in Indonesia in recent years (Figure 1).

In order to improve the halal tourism in Indonesia, the government through the Ministry of Tourism, Republic of Indonesia, in 2015 has appointed 13 provinces as prospective 
halal tourist destinations. Those provinces involve West Nusa Tenggara, Nangroe Aceh Darussalam, West Sumatera, Riau, Lampung, Banten, DKI Jakarta, West Jawa, Central Jawa, Yogyakarta, East Jawa, South Sulawesi, and Bali [4].

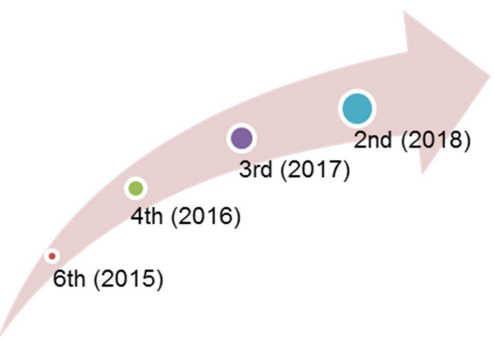

Figure 1. Indonesia's rank based on GMTI [3].

Unfortunately, the province of South Kalimantan was not included in the above list. Similarly, the Ministry also did not incorporate this province into 18 Indonesian favorite tourism destinations in the year 2018 [5]. It implies that the Ministry of Tourism assessed that this province has not yet the necessary readiness to develop halal tourism compared to above 13 provinces. This situation obviously obliges the local government to give more attention in order to improve the tourism industry. Therefore, this study attempts to reveal the potential of halal tourism in Banjarmasin as the capital of the province of South Kalimantan. The study is also intended to examine the challenges faced in promoting and developing the city as one of the prospective halal tourist destinations in Indonesia.

\section{Literature Review}

Tourist destinations are commonly determined by several attributes that are thought to attract tourists to visit those places. There are five key attributes of a tourist destination known as the "Five A" which includes accessibility, attractions, accommodation, amenities, and ancillary services [6]. Accessibility refers to the physical access to the tourism destination by any means of transportation through the air, maritime or land connectivity. Attractions motivate a tourist to travel which includes natural, cultural and social attractions. Accommodation means any supply of overnight facilities, hotels, guesthouses, campsites, etc. Amenities relates to various facilities and services provided at the destination which support the tourist destination. Ancillary services portray the provision of catering, entertainment, information at the destination, etc. [7]. Meanwhile, Buhalis proposed the attributes of a tourist destination with a new additional component which consist of accessibility, attractions, amenities, activities, ancillary services, and available packages [8].

\subsection{Halal Tourism Concept}

Halal tourism is one form of tourism that puts forward the values and norms of Islamic teaching as its basic foundation. The compliance with the Shariah is highly important as a guide in all aspects of tourism activities [9]. The concept of halal, derived from an Arabic word meaning 'allowed', is very important for Muslims. Therefore, halal tourism is part of the actualization of Islamic teaching in tourism activities where the values of halal and haram must be the fundamental reference for every actor in the tourism industry. This concept is applied not only in food but also in other products such as cosmetics, medicines, vaccines, financial products (banking, insurance, etc.), including tourism [1].

The use of term halal tourism still has not reached a consensus among academics, practitioners, and regulators. There are various terms to name this activity, among others Islamic tourism, halal tourism, halal travel, Muslim-friendly travel destinations, halal lifestyle, and others. Meanwhile, Battour and Ismail mention there are two terms that have been used most, namely Islamic tourism and halal tourism. Both are often considered the same and used interchangeably with each other [10].

\subsection{Halal Tourism Criteria and Measurement}

The development of halal tourism must be guided by the provisions of the Shariah as regulated in the Quran and the Prophet tradition. Technically, there are specific criteria that must be observed and should be provided in tourist destinations. The key faith-based needs of Muslim travelers are as follows: (1) Halal food. Halal food with proper halal assurance which is easily identifiable is the most important service that a Muslim traveler needs when traveling. (2) Prayer facilities. Prayer is the main worship and the second of the five pillars of Islam. Adequate prayer rooms need to be equipped in the services and facilities that are frequented by Muslim travelers. In support of this need, the prayer rooms need to have "foot washing" facilities for wudhu. (3) Ramadhan services. Muslim travelers have special needs during the month of fasting such as the catering of pre-dawn halal meals. (4) Water-friendly washrooms. Water plays an important role in purity and cleanliness for Muslims. It requires the use of water in the toilets. (5) No non-halal activities. Muslims travelers prefer to avoid facilities that serve alcohol, have discotheques or are adjacent to a gambling resort. (6) Recreational facilities \& services with privacy. Some Muslim travelers look for recreational facilities that provide privacy for males and females such as separate swimming pools and gyms [3].

Meanwhile, Chanin et al. [1] portrayed the following criteria to be fulfilled by halal industry which include: (1) the performing arts for tourists should not be contrary to the Shariah; (2) a prayer room should be provided, including with a washing facility and a Qibla direction bookmark; (3) a separate bathroom or toilet for men and women should be provided in a clean condition; (4) halal restaurants should be available at tourist destinations; (5) signposts and information on tour performances should be provided, both in English and Arabic; (6) security and order in every show and tourist destination must be guaranteed; (7) special therapists for men and women should be available at each spa; (8) motorists must carry out their duties in an orderly and cautious manner. 
The GMTI 2018 has adopted the latest set of measurements to better indicate the level of Muslim-friendly travel of each destination as shown in Figure 2. Based on this index, the measurement of the halal industry comprises access $(10 \%)$, communications $(15 \%)$, environment $(30 \%)$, and services $(45 \%)$.

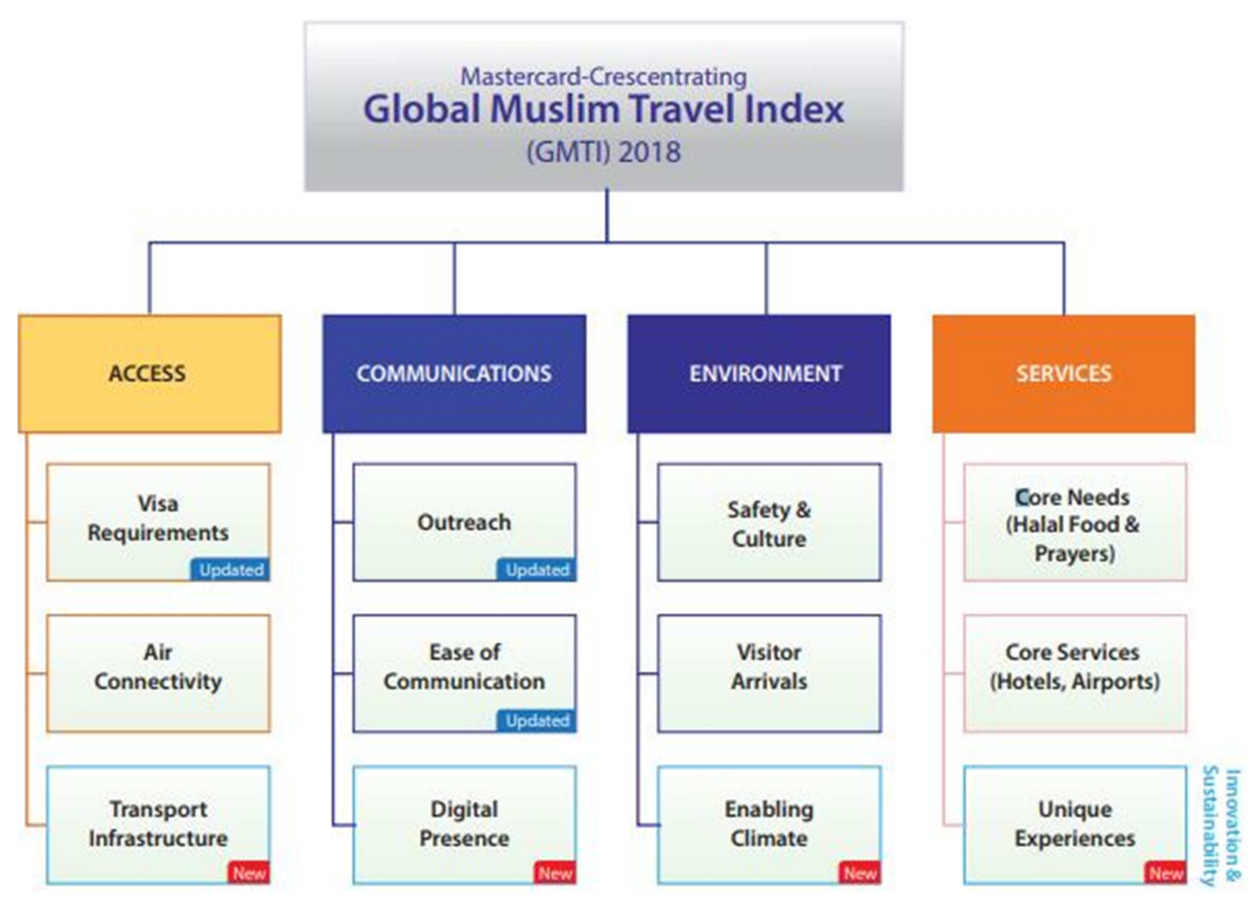

Figure 2. Measurement of GMTI 2018 [3].

\section{Methods}

This study was conducted using a qualitative approach. The data were collected from both primary and secondary sources. The primary data were gathered through interview and observation. The interviews were conducted with government officials in the Tourism Office of Banjarmasin and practitioners in the tourism industry while the observations were carried out in many tourist destinations around the city. Meanwhile, the secondary data were obtained from government regulation and documentation, media reports, as well as other relevant studies and researches. Data collected were then analyzed by using the descriptive-analytical method.

\section{Fascination of Banjarmasin}

This section discusses the collected data. It discusses the unique feature of Banjarmasin as a City of Thousand Rivers, the religiosity of its society, and local government roles to boost the halal tourism.

\subsection{A City of Thousand Rivers}

Banjarmasin is the capital of the province of South Kalimantan. It is a unique city and well known as a City of Thousand Rivers (Kota Seribu Sungai) owing to many rivers it has [11]. Banjarmasin has two great rivers which flow through the city, i.e. Barito River and Martapura River. These two rivers are interconnected to many other rivers, brooks and small streams throughout the city such as Kuin River, Alalak River, Pangeran River, Mulawarman River, Pelambuan River, and many others. The total number of rivers in Banjarmasin is 102 rivers. In addition to natural rivers and streams, Banjarese people also recognize three types of canals, i.e. anjir, handil, and saka [12]. Anjir is a primary water channel that connects between two rivers constructed for transportation and irrigation. Handil is a smaller water channel that originates from anjir constructed for irrigation. Meanwhile, saka is a tertiary water channel that originates from handil and commonly owned by a certain family or individuals.

In Banjarmasin, rivers possess an important role particularly for those whose houses are on its banks. The river supplies water for the people needs including for bathing and washing. It is also used for transportation and a source of livelihood for many people [13]. Business and economic activities are partly also taken place on the river which then becomes famous until now as floating markets (Pasar Terapung). All this forms a river culture for Banjarese people for centuries.

Nevertheless, with the passage of time, the importance of the river and its culture becomes less and misses its uniqueness. Development, unfortunately, has changed the course from river-oriented activities towards land-oriented activities [14]. Banjarmasin does not any longer follow the peculiar concept of a water city [15]. Roads and bridges were constructed massively replacing water transportation. Local wisdom in building construction is ignored by emerging new buildings that infringe the local identity [16]. Many houses 
and offices have been built excessively at the expense of small streams and rivers which then become disappeared or shrink. As a result, the environmental balance is disturbed and becomes a serious problem especially in the rainy season when the water cannot be channeled due to the disappearance of many streams around the city.

\subsection{The Religiosity of the Society}

Historically, Islam is estimated to come to South Kalimantan in the early $15^{\text {th }}$ century. The spread of Islamic in this region was further intensified by the establishment of the Sultanate Banjar by Pangeran Samudera approximately in 1540. He was previously a Hindu prince but converted to Islam and changed his name to Sultan Suriansyah. He then declared Islam as an official religion of the sultanate [17].

Islam and Banjar become like two sides of a single coin. Being a Muslim means becoming an Urang Banjar/Banjarese (the people of Banjar) [18]. There were many cases in which people from different ethnics and races, such as Dayak and Chinese, converted to Islam and subsequently considered a Banjarese (the people of Banjar). Therefore, Banjar at the outset is not a name of particular ethnic, but a religious, social, political and cultural entity. Islam and Banjar in South Kalimantan are indeed closely related and cannot be separated from each other. For Banjarese people, Islam is the spirit and the identity that forms and influences many aspects of their life [19]. Based on the 2010 census, $96 \%$ of South Kalimantan people are Muslim.

In terms of religiosity, Banjarese people are considered as practicing Muslims [18][19]. Thousands of mosques and langgar (small mosque) have been built all over the province showing the spiritual enthusiasm of the people to perform religious practices. Many of these holy places have regular religious instructions (majlis taklim) and the Quran kindergartens (Taman Pendidikan Al-Quran). These places are mainly self-financed by Muslim society through waqf and infaq. In addition, Banjarese people's religiosity can also be seen in many forms as manifested in their social and cultural life such as maulid (birth of the Prophet Muhammad) celebration, baayun maulid (swinging child ceremony), basunat (circumcision procession), batamat (completing the Quran recitation), marriage reception and many more.

\subsection{Government Roles}

Just in recent years, the local government of Banjarmasin indicated the seriousness to develop the halal tourism sector. It is encouraged mainly by the fact that the city has been recognized since long as a religious city and it actually possesses many potential halal tourist destinations. Having realized that the specific regulation concerning local tourism has never been issued before, the Mayor of Banjarmasin has then issued the Mayor Decree No. 25 the Year 2016 about Management and Developing River Based Tourism [20]. Although this decree does not mention halal tourism explicitly, it provides a necessary legal basis for developing the halal tourism industry in the city. This decree divides Banjarmasin into three developing zones: (1) Northern zone with 18 points of destination; (2) Western zone with 5 points of destination; and (3) Southern zone with 12 points of destination. Furthermore, in order to better manage this sector, a local regulation for halal tourism has also been drafting by the local government of Banjarmasin [21].

\subsection{Halal Tourist Destinations in Banjarmasin}

The author divides halal tourist destinations in Banjarmasin into four categories as follows: religious, natural, historical, and shopping and culinary tourist destinations.

\subsubsection{Religious Tourist Destinations}

Banjarmasin has many religious tourist destinations which include great and historical mosques and sacrosanct tombs of respected figures. The biggest mosque in Banjarmasin and constitutes a famous landmark of the city is the Great Mosque Sabilal Muhtadin. The mosque was built in 1981 and situated in the city center, on the west bank of Martapura River. The mosque building is magnificent, can accommodate around 15.000 people, equipped with 5 minarets, wide parking lot and city forest in its surroundings. Furthermore, Masjid Sultan Suriansyah or Masjid Kuin is the oldest mosque in South Kalimantan located in the bank of Kuin River, Kuin Utara, North Banjarmasin. The mosque was built at the time of Sultan Suriansyah (1526-1550), the first Sultan of Banjar who embraced Islam. Another remarkable mosque is Masjid Jami' Sungai Jingah constructed in 1777. Its building is dominated by Ironwood (ulin) with three layers of joglo architecture. Furthermore, Habib Basirih Dome is a sacrosanct tomb of Habib Hamid bin Abbas Bahasyim that becomes a popular object of pilgrimage tour in Banjarmasin. The dome which is located not far from the toll bridge to Trisakti Port is frequented by pilgrims not only from South Kalimantan and Indonesia but also from abroad.

\subsubsection{Natural Tourist Destinations}

Rivers are the advantage of Banjarmasin that really beautify this city. Many tourist spots lie around those rivers. The Menara Pandang is a four floor-tower that was built on the side of Martapura River. It offers beautiful views of the city. The tower was inaugurated in June 2014 and becomes a new landmark of the city. The development of the tower along with Siring Park was meant to strengthen the nickname of Banjarmasin as the "City of Thousand Rivers". In 2016, the local government developed Taman Siring 0 kilometer as a particular location in Banjarmasin from which its zero kilometer distance is traditionally measured. Besides, there is Taman Maskot Bekantan, a park along the Siring of Martapura River installed with a Long Nose Monkey (Bekantan) statue which reaches almost 7 meters high. Taman Maskot Bekantan is a pleasant and interesting place to be visited. It is loaded by visitors in the weekend and holidays. Meanwhile, Taman Satwa Jahri Saleh is a park zoo 
and home to a number of creatures from poultry, reptiles, primate, and other species. Located on Jahri Saleh Street, Surgi Mufti, it was developed in 1999. Taman Satwa Jahri Saleh is a safe and pleasant place for visitors including children and constitutes an education park as well.

\subsubsection{Historical Tourist Destinations}

Several historical tourist destinations are also available in Banjarmasin, for instance, Rumah Anno 1925, Museum Wasaka, and Prince Antasari's memorial park. Rumah Anno was built in 1925 AD, located on Tendean Street. This house is one of house building of Palimasan, two-floor type of house that still exists in Banjarmasin. Along with Tendean floating market which is located in the same area, Rumah Anno has good facilities such as parking area, prayer room, halal food, and clean toilet. Meanwhile, Museum Wasaka is a museum of the struggle of South Borneo people. Wasaka stands for "Waja Sampai Kaputing" which is the motto of South Kalimantan people. It was inaugurated in 1991, housed in Rumah Banjar Bubungan Tinggi which was later transformed from a residential building to a museum. Another historical site is Prince Antasari's memorial park. Prince Antasari is a local warrior who has been conferred an honor as a National Hero of Indonesia. He was buried in a funeral complex located on Malkon Temon Street, North Banjarmasin.

\subsubsection{Shopping and Culinary Tourist Destinations}

Like any other major city in the country, Banjarmasin has numerous shopping centers and modern markets. What is different from Banjarmasin is the existence of traditional river markets which provides a unique experience for visitors. There are two river markets in Banjarmasin area, i.e. Kuin floating market and Tendean floating market. Kuin Floating Market is a natural floating market, located on the estuary of Barito River, Kuin Utara. This market is estimated to have existed about 400 years ago. In this market, traders and buyers using boats called jukung to conduct sale and purchase transactions. Surely, it offers a wonderful experience since all tourists must use a boat to get to the place. Kuin floating market attracts many visitors both from domestic and foreign. However, this market takes place only shortly starting after Fajr prayer until about seven o'clock in the morning.

In order to conserve the floating market tradition, Government of Banjarmasin initiated a new floating market at the Siring of Martapura River on Pierre Tendean Street. In contrast to Kuin floating market, Tendean floating market is located in the city center and facilitated with some conveniences such as adequate parking area, small mosque, and toilets. The government also provides this area with dock for kelotok (boat) that can be used for river tour around Banjarmasin. There is another distinctive shopping area called Kampung Sasirangan. It is a small village where Banjarmasin typical fabrics namely sasirangan is widely produced by its residents. In this area, visitors can see the process of making sasirangan. Meanwhile, culinary destinations are available in many spots throughout
Banjarmasin, but the most notable of those culinary spots are apparently Soto Banjar Bang Amat. Soto Banjar is a typical food of South Kalimantan with a special taste which is different from other types of soto in other parts of Indonesia. This restaurant is located alongside the Martapura River. Here, visitors can enjoy not only a delicious meal but also beautiful river sights. Other than soto, Banjarmasin also has many other delicious foods such as ketupat, lontong, nasi kuning and a big variety of traditional cakes.

\section{Challenges}

This section analyzes the conditions and challenges faced by Banjarmasin in promoting and developing the city as a favorite halal tourist destination in Indonesia. The analysis is carried out mainly by referring to the GMTI 2018 because this index is used by the government as a reference for standardizing the halal tourism industry in Indonesia.

\subsection{Access}

Visa requirements for entering Indonesia are much easier now because the government has opened visa-free access for tourists from various countries to come to Indonesia. But because Banjarmasin has not yet served international flights, tourists who want to go to this city must enter through other airports such as Jakarta, Surabaya or Balikpapan. The absence of an international airport is one of Banjarmasin's main weaknesses as a tourist city in attracting foreign tourists.

While transport infrastructure in Banjarmasin generally is quite good, the public transportation route is limited. Due to the lack of public transportation, visitors must use private transportation to reach many tourist destinations. Meanwhile, the increasing growth of private vehicles without sufficient expansion of roads has added to the congestion of the streets in the city especially during rush hours in the morning and evening. Therefore, the government needs to provide special transportation for tourists to arrive at halal tourist places more easily. In this case, water transportation becomes an appropriate solution because it is suitable for the image of Banjarmasin as the city of Thousand Rivers.

\subsection{Communications}

The promotion of halal tourism in Banjarmasin needs to be improved using any means and media. Overseas promotions also need to be intensified. Meanwhile, unlike other cities in Indonesia such as Yogyakarta and Denpasar where many tourism industry players have become accustomed to foreign languages, especially English, Banjarmasin requires more translators and tour guides. Tour guides need to be prepared at various tourist destinations to help visitors in their journey in this city.

The Tourism Office of Banjarmasin government has already a website that promotes tourist attractions and destinations in this city, but the language used in such a website is only Indonesian so that foreign tourists have 
difficulty to access it. The website must always be updated and enriched all the time with the latest information. For tourist destinations in Banjarmasin, it is very rare that they have their own website.

\subsection{Environment}

The level of security in Banjarmasin is generally quite conducive, but in crowded places such as markets, theft or snatching sometimes still occurs. With regard to cleanliness, Banjarmasin has for several years received a Clean City Award (Piala Adipura) from the Ministry of Environment, the Republic of Indonesia. However, river cleanliness is still a serious challenge for the government. Among the biggest problems is the amount of garbage coming from upstream areas. The garbage must be cleaned up before entering into the city so that the view of the river which constitutes the mainstay of the city river tour is maintained. The safety and security factors of river transportation should also be enhanced with routine inspections for all ships and the obligation to use buoys for all passengers. In addition, the design of the ship or kelotok may need to be changed so that passengers no longer climb to the roof to enjoy the beauty of the river panorama. River tour packages must also be provided more attractive not only to people who stay in hotels but also to the wider community.

The number of tourist arrivals every year continues to increase, including foreign tourists. Excellent facilities and services accompanied by promotions must be optimized to further increase the number of tourist visits. In the meantime, rules concerning the obligation to close aurat and banning seclusion for a non-mahram couple in public places are not yet available. The government needs to regulate it so that the rules of Shari'ah can be enforced well for the common comfort and orderliness.

\subsection{Services}

Halal food with a variety of menus can be found very easily in Banjarmasin because the majority of tourist service providers and residents of Banjarmasin are Muslims. Halal food is also available for tourists at the Syamsuddin Noor airport. However, the lack of restaurants and food providers having halal certificate from MUI is still a big challenge for this city. The people awareness about the urgency of halal certification still needs to be improved. In addition, all restaurants and food stalls should provide a menu list with their prices for ease for travelers. Places of worship for Muslim visitors in Banjarmasin are not difficult to obtain because there are a lot of mosques and small mosques (langgar) in various places. Information about the time of prayers is therefore available all the time because adzan (a call to prayer) can be heard from those holy places. Clean water for ablution is also available sufficiently. However, separate toilets for men and women are still not widely available in most of the tourist destinations.

In terms of accommodation, Banjarmasin already has many hotels and inns. Based on the data from the Indonesian
Association of Hotels and Restaurants (PHRI) of South Kalimantan, there are 150 hotels in Banjarmasin, but very few hotels have already been certified. Only $5 \%$ of hotel has already received the certificate for their product, service, and management. There are several Shariah hotels located in Banjarmasin and some others are outside Banjarmasin, which is Banjarbaru.

Regarding the unique experiences related to Islamic heritage sites, there are two very well-known and most visited graves near Banjarmasin, namely the tomb of Syekh Arsyad Al-Banjari in Kelampayan and Syekh Zaini Abdul Ghani in Sekumpul, both located in Martapura about $40 \mathrm{~km}$ from Banjarmasin. Hundreds of thousands of people come to these places to commemorate their deaths (haul) every year and many of them are coming from outside South Kalimantan and Indonesia, such as Malaysia, Singapore, and Brunei. During these great events, hotel occupancy rates are usually very high and airline tickets are sold out. This also causes severe traffic congestions around Martapura due to a large number of people who are coming.

\section{Conclusion}

Banjarmasin is bestowed with the splendor of religious, natural, historical as well as shopping and culinary tourist destinations. All these provide a big opportunity to attract both domestic and overseas visitors. The prospect of halal tourism in Banjarmasin is therefore quite promising given the available resources and religious character of the people. Nonetheless, the city still faces some challenges that need to be addressed with collaborative and coordinative actions from all stakeholders.

A number of strategic and technical efforts are required to further improve the access, communications, environment, and services of this halal industry. All stakeholders of this industry ranging from government, business operators and owners as well as the public at large need to work hand in hand to provide better service and to offer unforgettable moments for those visiting this city. The government needs to strengthen the regulation and provide supporting programs and facilities that can better manage and encourage the industry to grow. Business operators and owners need to improve their business capacity and provide professional services to visitors as well as to make the necessary investment to boost the industry. Finally, the public at large are expected to support this growing industry through their hospitality and maintaining the cleanliness and orderliness of the city.

\section{Acknowledgements}

This article would never materialize without the support from the Ministry of Research, Technology, and Higher Education, the Republic of Indonesia through the grant of Inter-University Cooperation Research (Penelitian Kerjasama Antar Perguruan Tinggi) in the year of 2018.

The initial draft of this manuscript has been presented at 
the International Conference on Applied Science and Technology (iCAST), in Manado, Indonesia, on October 2627,2018 .

\section{References}

[1] Chanin, Oraphan, Sriprasert, Piangpis, Rahman, Hamzah Abd, \& Don, Mohd Sobri. (2015). Guidelines on Halal Tourism Management in the Andaman Sea Coast of Thailand. Journal of Economics, Business, and Management, 3 (8), 791-794.

[2] Kementerian-Pariwisata. (2015). Rencana Strategis Pengembangan Destinasi dan Industri Pariwisata Tahun 2015 - 2019 (Renstra PDIP 2015 - 2019). Jakarta: Deputi Bidang Pengembangan Destinasi dan Industri Pariwisata Kementerian Pariwisata.

[3] Mastercard-Crescentrating. (2018). Global Muslim Travel Index 2018

[4] Ardianto, Robi. (2015, 27 April). 13 Provinsi Siap Jadi Tujuan Wisata Syariah, Koran SINDO. Retrieved from https://nasional.sindonews.com/read/994208/162/13-provinsisiap-jadi-tujuan-wisata-syariah-1430102126 (20 June 2017).

[5] Prokalsel. (2017, 14 Desember). Marasnya..!! Pariwisata Kalsel Tak Dilirik Kemenpar, Prokalsel.

[6] Cooper, C, Fletcher, J, Fyall, A, Gilbert, D, \& Wanhill, S. (2008). Tourism: Principles and Practice, Pearson Education, Harlow (4 ed.).

[7] Sukiman, Mohd Fauzi, Omar, Shida Irwana, Muhibudin, Masitah, Yussof, Izatul, \& Mohamed, Badaruddin. (2013). Tourist Satisfaction as the Key to Destination Survival in Pahang. Procedia-Social and Behavioral Sciences, 91, 78-87.

[8] Buhalis, Dimitrios. (2000). Marketing the competitive destination of the future: Growth strategies for accommodation establishments in Alpine regions. Tourism Management, 21 (1), 97-116.

[9] Widagdyo, Kurniawan Gilang. (2015). Analisis Pasar Pariwisata Halal Indonesia. The Journal of Tauhidinomics, 1 (1), 73-80.
[10] Battour, Mohamed, \& Ismail, Mohd Nazari. (2015). Halal tourism: Concepts, practices, challenges, and future. Tourism Management Perspectives, 19-B, 150-154.

[11] Sugianti, Desy. (2016). Strategi Pengembangan Kawasan Wisata Pasar Terapung Berbasis Kearifan Lokal di Kota Banjarmasin. Tata Kelola Seni, 2 (2), 20-34.

[12] Subiyakto, Bambang. (2005). Arti Penting Perairan Bagi Transportasi Masyarakat Banjar. Kandil, 9 (Mei-Juli)

[13] Rochgiyanti. (2011). Fungsi Sungai bagi Masyarakat di Tepian Sungai Kuin Kota Banjarmasin. Komunitas, 3 (1), 51-59.

[14] Goenmiandari, Betty. (2010). Konsep Penataan Permukiman Bantaran Sungai di Kota Banjarmasin Berdasarkan Budaya Setempat. (Tesis), Institut Teknologi Sepuluh Nopember, Surabaya.

[15] Hadinata, Irwan Yudha. (2010). Tipomorfologi Kota Banjarmasin: Kawasan Inti Kota Banjarmasin. (Tesis), Universitas Gadjah Mada, Yogyakarta.

[16] Jaya, Edi. (2009). Kajian Fisik Ruang Sepanjang Tepian Sungai di Kelurahan Alalak, Kota Banjarmasin. (Tesis), Universitas Diponegoro, Semarang.

[17] Buseri, Kamrani. (2011). Budaya spiritual Kesultanan Banjar: Historisitas dan relevansinya di masa kini. Paper presented at the Seminar Penguatan Budaya Banjar dan Peran Kesultanan dalam Menjawab Tantangan Zaman, 8 December, Banjarmasin.

[18] Bustamam, Ridwan. (2012). Mengenal Ulama Melalui Inskripsi Keagamaan (Studi Kasus di Martapura Kalimantan Selatan). Jurnal Lektur Keagamaan, 10 (2), 373-406.

[19] Daud, Alfani. (1997). Islam dan Masyarakat Banjar: Deskripsi dan Analisa Kebudayaan Banjar. Jakarta: Rajawali Press.

[20] Peraturan Walikota Banjarmasin No. 25 Tahun 2016 tentang Pengelolaan dan Pengembangan Wisata Berbasis Sungai.

[21] Prokalsel. (2018, 20 April). Pemko Ajukan Perda Wisata Halal di Banjarmasin. 